\title{
Non-seismic Geophysical Prospecting Model of Beiya Gold Mine in Western Yunnan Province
}

\author{
(Model Pencarigalian Geofizik Tak Seismik Lombong Emas Beiya di Wilayah Barat Yunnan)
}

\author{
Jian Yang*, Qiao Wang, Shengxian Liang, Jing Guo \& Muhammad Aqeel Ashraf
}

\begin{abstract}
According to the basic rules and characteristics of the gold-polymetallic deposits of Beiya gold mine area in terms of mineralization and ore controlling, it is concluded that skarn deposit is the main ore deposit type in this area and the geological conditions are analyzed by the statistics of the physical parameters. Then, the tectonic, rocks, stratum, ore geophysical models have been treated by the forward modeling numerical simulation and the results are analyzed comprehensively. Based on the forward modeling results, combined with the relevant physical differences, the principle and exploration method test and research for the comprehensive geophysical exploration technology has been carried out, covering the induced polarization and magnetic prospecting for the ore body as well as the indirect geophysical exploration method by means of plane gravity data, audio-magnetotelluric sounding for rock mass and tectonics, the mineralization mode-physical forward modeling - geophysical exploration mode has been established and good results have been achieved. Therefore, a location forecast method has been put forward for the concealed skarn type Fe-Au deposit which is adaptive to the mineralized geological background of Beiya and other similar areas.
\end{abstract}

Keywords: Beiya gold ore; forward modeling; prospecting model

ABSTRAK

Menurut peraturan asas dan ciri timbunan polilogam emas di kawasan lombong emas Beiya daripada segi mineralisasi dan pengawalan bijih, dapat disimpulkan bahawa timbunan skarn adalah timbunan bijih utama di kawasan ini dan keadaan geologinya dianalisis oleh parameter fizikal statistik. Seterusnya, model tektonik, batuan, strata dan geofizik bijih telah dirawat menggunakan model ke hadapan simulasi berangka dan hasilnya dianalisis secara menyeluruh. Berdasarkan hasil pemodelan ke hadapan, digabungkan dengan perbezaan fizikal yang relevan, kaedah pengujian dan penyelidikan prinsip dan eksplorasi untuk teknologi eksplorasi geofizik yang komprehensif telah dijalankan, meliputi kaedah polarisasi teraruh dan pencarigalian magnet untuk jisim bijih serta kaedah penerokaan geofizik tidak langsung dengan menggunakan data graviti pesawat, bunyi magnetotellurik untuk jisim batuan dan tektonik, mod mineralisasi pemodelan fizikal ke hadapan - mod penerokaan geofizik telah dibentuk dan keputusan yang baik telah dicapai. Oleh itu, kaedah ramalan lokasi dikemukakan bagi mengesean timbunan skarn jenis Fe-Au tersembunyi yang mudah sesuai dengan latar belakang geologi mineral di kawasan Beiya dan kawasan yang sama.

Kata kunci : bijih emas Beiya; model pencarigalian; pemodelan ke hadapan

\section{INTRODUCTION}

With the increasing prospecting and exploitation of mineral resources and the increasing reduction of the identifiable ores, surface ores and shallow layer ores, the prospecting work is putting more emphasis on looking for the unidentifiable, concealed and deep ores. In front of this transformation, people tend to refer the combination of gravity-magnetic-electric prospecting to develop the integrated geophysical methods (Liu \& Hao 1995).

Beiya Mine Area in western Yunnan is located in the west of Yangtze Platform, southwest of Qinghai-Tibetan Plateau, located at the projecting area between the arcbasin system of the southwestern three rivers and upper
Yangtze platform. Featuring the special tectonic location and complex history of the crustal evolution, favorable metallogenic conditions and abundant mineral resources, Beiya Mine Area is an ideal place for looking for many precious, scarce or rare mineral resources. In recent years, it has become one of the most important strategic reserve bases in China's southwestern areas.

This area presents diversified mineralization modes and complex mineral deposits and is affected by the alkali-rich porphyry, tectonics and formation. Many scholars have conducted a wide range of studies from different perspectives based on the mineralization modes and rules, therefore, the cause for the deposits becomes 
a controversial question. However, almost all of scholars believe that the dominating type of ultra-large goldpolymetallic deposits of Beiya Gold Mine Area is the alkali-rich porphyry contact zone skarn (He et al. 2013). Controlled by the rock mass-tectonics- layer, the contact alteration zone of the rock mass and carbonate rock is the favorable part of the skarn type ore deposit (Li et al. 2016). According to the metallogenic model like Beiya, most of the research on and practice of the prospecting method is mostly and purely based on the deposit and mineralization, but ignoring some indirect prospecting information and the workload is limited, especially new technology and new methods are less frequently used. The available work fruits and data are not based on sufficient study, which fails to efficiently explain the abnormity. There is a lack of systematic and deeper prospecting model study on the special geological conditions for regional tectonics, rock mass, stratum and mineralization in Beiya and no direct technical method system for prospecting has been formed yet and the comprehensive geophysical exploration mode adaptive to this region has not been established yet (Wu et al. 2017).

A variety of geological and geophysical methods have been used to extract the abnormal information, in order to determine the potential rock contact zone. With regard to the spatial contact relationship between the rock mass, tectonics and layer, the magnetotelluric sounding has a significant advantage in the non-seismic geophysical exploration. Gravity exploration is the most important method for looking for regional tectonics and delineating concealed rock mass, magnetic exploration is the most important method of the deep iron ore exploration and induced polarization method is an important means of directly positioning sulfide ores. The researchers carried out in-depth research on some methods, without carrying out the integration research (Liu et al. 2016). Many scholars have taken advantage of multiple information technology, done a lot of beneficial exploration in mineral prediction and made a number of important achievements (Xiao et al. 1999). Their study was based on the regional or local prospecting prediction and research, lacking the comprehensive study from the surface to point and from forward modeling test to the actual exploration verification (Sultana et al. 2017). This paper, from the mineralization mode to the exploration mode in Beiya Mine Area, are based on the basic research on the physical properties of rock ores, discusses the efficiency and adaptability by establishing the forward modeling for the rock masses, tectonics and ores in accordance with the known geological structure and carrying out the geophysical prospecting test based on the forward modeling. This paper, from the surface to point, has developed the non-seismic geophysical prospecting mode in Beiya Mine Area based on the multiple information restrictions both theoretically and practically and satisfactory exploration results have been made.

\section{Geological PROfile}

\section{REGIONAL GEOLOGY AND GEOLOGICAL CHARACTERISTICS OF MINING AREA}

Beiya Mine Area is located in the east of five Class I tectonic units of Dege-Zhongdian Landmass, Yangtze Landmass, Lanping-Simao Landmass (Figure 1), between Jinsha River - Honghe River Fault, Binchuan - Chenghai Fault and Lijiang - Muli Fault, categorized into the continental rift environment, with characteristics of tension rift. The mine area is located at Lijiang platform margin depression fold zone in the west of Yangtze quasiplatform, which belongs to Dali-Lijiang mineralization concentration area in the middle and southern section of Yangtze Mineralization Area in Yunnan (Yin et al. 2012). The Upper Sinian, Cambrian and Ordovician strata are scattered sporadically in the area and Permian to Quaternary landform is mainly outcropping. In the region, the tectonic activities are frequent, the tectonic deformation is complex and the overall direction of the fracture is nearly NS and the near WE direction is also developed. The subduction and collision of Indian plate of Himalayan Period towards the Eurasian plate caused the face-to-face subduction between Indian plate and Yangtze plate, which gives rise to the formation of massive strike-slip faults, pull-apart basins and emplacement of alkali-rich porphyry, accompanied by a series of deposit formation. This Intracontinental porphyry metallogenic zone distributed in Yanyuan - Lijiang faulted basin is a porphyry metallogenic zone which is closely linked with and also relatively independent from Jinsha River - Ailaoshan porphyry zone, which is deemed as the remote response to the Indian - Eurasia continent collision orogenic diagenism mineralization in this area at the stress transformation stage.

The mining area is generally controlled by the NNE syncline and the syncline kernel is mostly covered by Holocene and Pleistocene sediments, while wings were affected by faults and magma intrusion and small folds have been developed (Figure 2). The strata in the mine area, from the older to later, mainly include Quaternary Holocene alluvial gravel and clay and Pleistocene sedimentary facies and lacustrine facies tuffaceous breccia. The river and lake facies contains the gravel clay and gravel rocks. The middle and upper part of Beiya Formation (T2b4) features graywhite microcrystalline dolomite and dolomite with light gray debris, gradually changing downward to the gray and dark gray grained dolomite and microcrystalline dolomite (T2b3) of interstratification production; the lower part of Beiya Formation (T2b1+2) is gray, light gray, middle and thick layer of nodular and vermicular (bioclastic) limestone and argillaceous limestone, containing sand argillaceous clastic rocks thin layer; and Qingtianbao Formation (T1q) is yellowish brown and grayish green lithic quartz sandstone, containing the yellowish green and purplish red shale layer. 


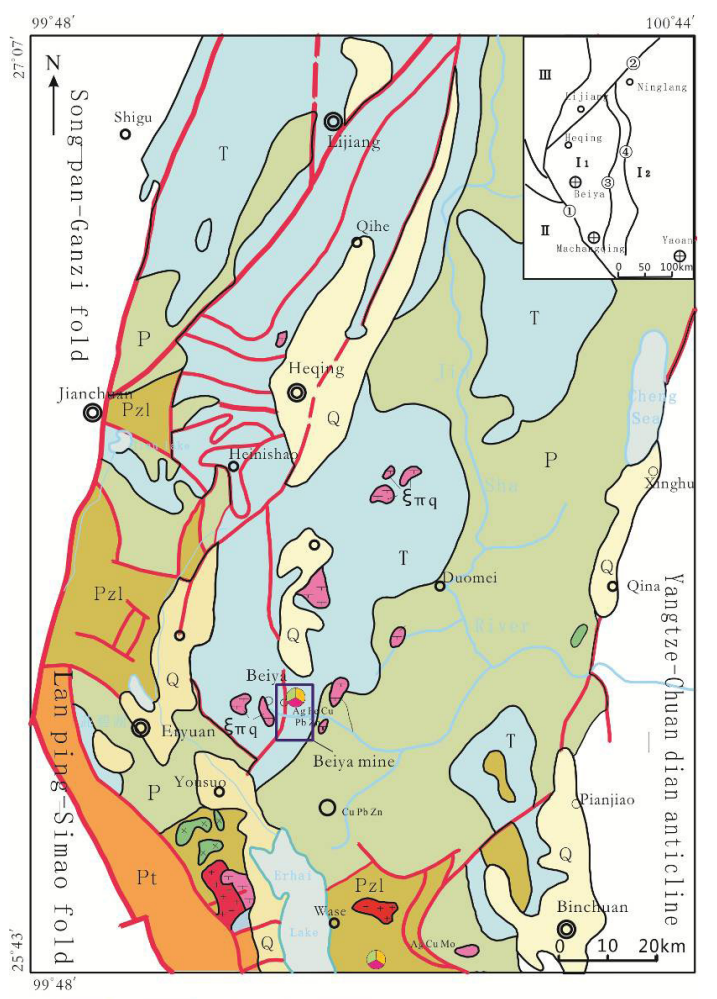

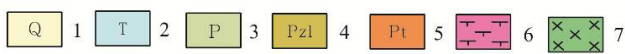

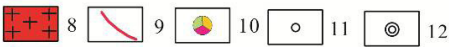

1-Quaternary; 2-Triassic; 3-Permian; 4-Lower Paleozoic; 5-Proterozoic; 6-Orthophyre; 7-Basic rock; 8-Granite; 9-Fault and inferred fault; 10-Large deposit;

11-Small and medium-sized deposit; 12-Cities and counties; 13-Village I 1-Western margin of the Yangtze- Lijiang platform edge fold belt; I 2-Yangtze Platform-ChuanDian (Sichuan and Yunnan) platform anticline; II—Lanping-Simao fold belt; III-Songpan-Garze fold belt

(1)-Jinshajiang-Honghe fault; (2)-Lijiang-Muli fault; (3) - Chenghai-Binchuan fault; (4)-Yongsheng-Xiangyun fault

FIGURE 1. Regional geological map of west Yunnan China (modified after Regional Geology of Yunnan Province, 1990)

In the mining area, there are many tensional and tensional faults, including the NE, NS and WE directions. NE and near the North-South faults are a pre-mine fracture and contemporaneous faults, which are the channel for alkali-rich magma intrusion and fluid migration and also an important ore-bearing structure (Sirajuddin et al. 2015). It controls the spatial distribution of rock mass and the mineralization scale. For Wandongshan ore section at the west wing of the syncline, the strata is affected by the alkali-rich magma diapir upwelling. A dome structure has been formed as the center of the structure and the rock mass contact zone and fault crushed zone are the important ore-controlling tectonics. The secondary faults around the 'dome', strata bedding slip zone and fractured joints have controlled the mineralization scale, occurrence and enrichment to some extent. The development of late EW faults destroyed early ore bodies.

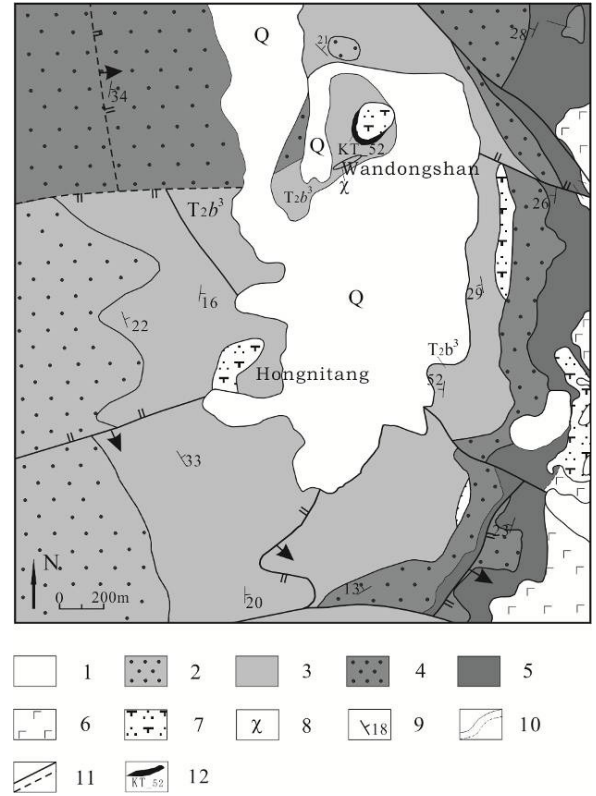

1-Quaternary gravel clay layer; 2-Beiya Formation, 4th member dolomite; 3-Beiya Formation, 3rd member dolomite; 4-Beiya Formation, 1st and 2nd member limestone; 5-Qingtianbao Formation, sandstone; 6-Emeishan basalt; 7-Quartaorthophyre; 8-Lamprophyre vein; 9-Attittude; 10-Measured and inferred geological boundaries; 11-Measured and inferred faults; 12-Orebody and its serial number

FIGURE 2. Geological map of the Beiya Au-polymetallic deposit

\section{GEOLOGICAL FEATURES OF TYPICAL DEPOSITS}

The mineralization of gold-polymetallic deposits of Beiya Gold Mine Area is strictly under control of the alkalirich porphyry magma and gas-liquid evolution process. According to the ore (mineralized) body formation and occurrence characteristics, the deposits can be divided into the porphyry copper-gold mineralization (body), banded skarn iron copper-gold ore vein and vein and vesicular filling penetration iron ore body. Among them, skarn iron copper-gold mineralization is the most prevailing mineralization type of Beiya Mine Area. As shown in No. 56 exploration line profile (Figure 3 ) of Mine Area, the mine body generally surrounds the rock masses as the central occurrence, the skarn ore body is controlled by the contact zone and the harbor shaped part is the most developed. Based on the latest progress on the mineral research work, it is concluded that Beiya Mine Area is mainly caused by the gas-liquid metasomatic mineralization and skarn type copper-gold ore deposit. The orebody is strictly controlled by the tectonics of rock mass contact zone, which shows the layers of irregular bedded and lenticular patterns, with good continuity. In the early stages, skarn was developed into similar iron ores, which were produced in the skarn alteration zone of the contact zone between the porphyry and the surrounding rock and the metallic minerals are mainly magnetite, coexisting with garnet, diopside and 
other skarn minerals. At the late quartz sulfide metallogenic period, silicification and carbonatization alteration will take the leading role, and metal minerals mainly include pyrite, pyrrhotite, chalcopyrite and other metal sulfides. Pyrite magnetite is the major gold carrier, and gold fills in the early iron core fissures or weathered holes, and or exists in the oxidized limonite on the near surface, which forms the 'honeycomb' magnetite -hematite, therefore the pyrite, chalcopyrite and other ores with imposed metal sulfide has a high gold content (magnetite ore not containing pyrite $0.27 \sim 2.32 \mathrm{~g} / \mathrm{t}$, magnetite-hematite ore containing pyrite $9.13 \sim 34.50 \mathrm{~g} / \mathrm{t}$ and honeycomb oxidized limonite $17.90 \sim 30.20 \mathrm{~g} / \mathrm{t}$ ). Therefore, gold is believed to be mineralized with the late pyrite, chalcopyrite and other metal sulfides, so it is concluded that 'gold is destined to be in the company of iron'.

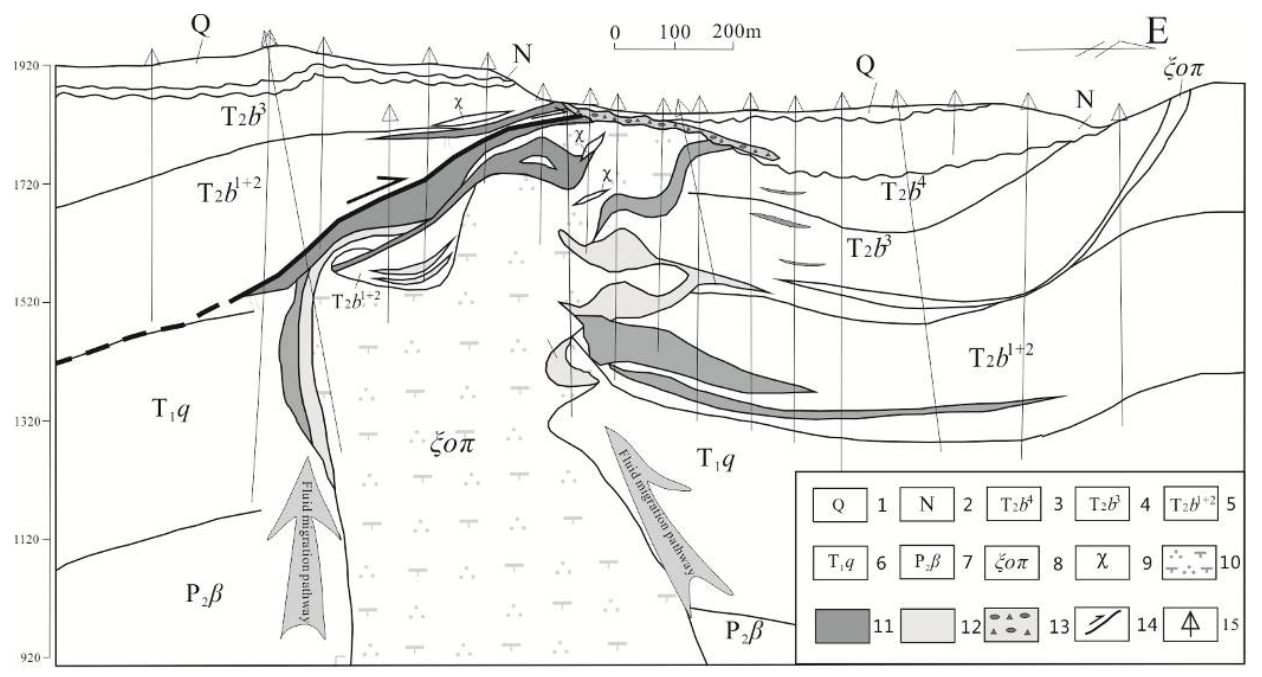

1-Quaternary Pleistocene Series breccia; 2-Neogene fluvial-lacustrine sediments; 3-Middle Triassic Beiya Formation, 4th member dolomite; 4-Middle Triassic Beiya Formation, 3th member dolomite; 5-Middle Triassic Beiya Formation, 1th and 2th member limestone; 6-Lower Triassic Qingtianbao Formation; 7-Emeishan basalt; 8-Himalayan quartz-orthophyre; 9-Lamprophyre dike; 10- Orthophyre; 11-Fill-in type orebody; 12-Skarn type orebody; 13-Residual and diluvial type orebody; 14-Fault; 15-Drill hole

FIGURE 3. Geological section along No. 56 exploration line and deposit types in the Beiya goldpolymetallic deposit

\section{PROSPECTING MARK}

Based on the strata, structure, magmatite ore characteristics, mineralization characteristics and metallogenic mechanism, Beiya type gas-liquid metasomatic mineralization and skarn type copper-gold ore deposit prospecting marks are summed up as 'tectonic rock control and mineralization by rock masses, where tectonics, rock masses and stratum are combined as one' (Sirajuddin et al. 2015). The fault tectonics affects the intrusive position of the rock mass and the contact between the rock mass and the surrounding rock generates the Fe-Au polymetallic mineralization, which is the prospecting mark geologically. The prospecting marks include low weight anomaly for rock masses, high magnetism anomaly for $\mathrm{Fe}-\mathrm{Au}$ ore body, polarization anomaly of sulfide minerals and high resistivity anomaly of carbonate rock. In the later stage of exploration, the corresponding geophysical method shall be carried out for the above marks.

\section{PHYSICAL PROPERTIES AND FORWARD MODELING}

\section{PHYSICAL PROPERTIES OF ROCK ORES}

The rocks outcropping in the study area mainly includes dolomite, limestone, sandstone, basalt and quartz syenite porphyry and the physical measurements have been done in this study area to clarify the physical differences between rocks and ores. The measurement includes density, magnetic susceptibility, resistivity and polarizability. According to statistics, limestone and dolomite are similar in terms of resistivity, polarizability, density and magnetic susceptibility. In view of the geophysical method resolution, these rocks cannot be easily divided, so limestone and dolomite of Beiya Formation should be considered by categorizing them into the carbonate rock. The samples of iron ore were collected from Wandongshan Quarry, which is mainly distributed in the outer contact zone of the rock mass. 
TABLE 1. Statistic results of physical properties samples of rock (ore) minerals

\begin{tabular}{lccccccccc}
\hline & $\begin{array}{c}\text { Sample } \\
\text { number }\end{array}$ & \multicolumn{2}{c}{ Resistivity $(\Omega \bullet \mathrm{m})$} & \multicolumn{2}{c}{ Polarizability $(\%)$} & \multicolumn{2}{c}{ Density $\left(\mathrm{g} / \mathrm{cm}^{3}\right)$} & \multicolumn{2}{c}{$\begin{array}{c}\text { Magnetic susceptibility } \\
\mathrm{K}(4 \pi * 10-6 \mathrm{SI})\end{array}$} \\
\hline & & \multicolumn{2}{c}{ Change variation } & Mean & $\begin{array}{c}\text { Change } \\
\text { value }\end{array}$ & $\begin{array}{c}\text { Mean } \\
\text { variation } \\
\text { value }\end{array}$ & $\begin{array}{c}\text { Change } \\
\text { variation }\end{array}$ & $\begin{array}{c}\text { Mean } \\
\text { value }\end{array}$ & $\begin{array}{c}\text { Change variation } \\
\text { Mean } \\
\text { value }\end{array}$ \\
Limestone & 84 & $2057.1 \sim 6774$ & 4171.6 & $0.8 \sim 4.6$ & 1.8 & $2.65 \sim 2.83$ & 2.68 & $2 \sim 1183$ & 364 \\
Dolomite & 78 & $1327.8 \sim 5974.9$ & 3049.3 & $1.22 \sim 11$ & 1.5 & $2.61 \sim 2.78$ & 2.64 & $4 \sim 1026$ & 342 \\
Sandstone & 85 & $75.8 \sim 2379$ & 378.1 & $0.29 \sim 9$ & 1.14 & $2.73 \sim 2.86$ & 2.8 & $4 \sim 382$ & 66 \\
Basalt & 90 & $499.9 \sim 1200$ & 836.5 & $1.16 \sim 2.95$ & 2.6 & $2.51 \sim 3.08$ & 2.81 & $1239 \sim 58104$ & 5147 \\
Porphyry & 70 & $113.2 \sim 2415$ & 556.2 & $1.17 \sim 9.6$ & 3.4 & $2.12 \sim 2.68$ & 2.54 & $721 \sim 988$ & 841 \\
Skarn & 24 & $758.3 \sim 3652.1$ & 1258.7 & $1.8 \sim 4.4$ & 3.3 & $2.66 \sim 3.77$ & 3.15 & $1521 \sim 5219$ & 2063 \\
Iron core & 80 & $10 \sim 699.2$ & 137.1 & $5.7 \sim 66.2$ & 14.4 & $2.97 \sim 4.91$ & 4.14 & $2249 \sim 167740$ & 51570 \\
\hline
\end{tabular}

From Table 1, it can be seen that the geophysical properties of rocks and ores include the following: the carbonate rocks feature high resistivity, with low polarizability; sandstones feature low resistivity and low polarizability; basalt has the medium to high resistivity, with medium to low polarizability; porphyry features medium to low resistivity, with medium to high polarizability; and iron ore features low resistivity and high polarizability. There is a great difference between the resistivity of rocks in different strata, and the resistivity information is utilized to classify the boundary of the stratum. The porphyry density is less than the density of sedimentary rock. The porphyry is a low-density body in the study area, which can produce abnormal low density and the low-density characteristics of rock masses are utilized to determine the geometric structure of rock masses. Iron ore and basalt are high magnets, but sedimentary rocks and porphyry are less magnetic. The electrical sounding method can solve the issue of deep buried basalt, and the impacts of the produced high magnetism will be addressed accordingly. Regardless of the interruption of basalt, the abnormal magnetic information will be utilized to further determine the favorable accumulation area of deposits. The polarizability difference between the ore and surrounding rocks (iron ore and the porphyry and the carbonate rock) is more than $2.37 \%$ and the polarizability parameters can be utilized to effectively follow up the orebody.

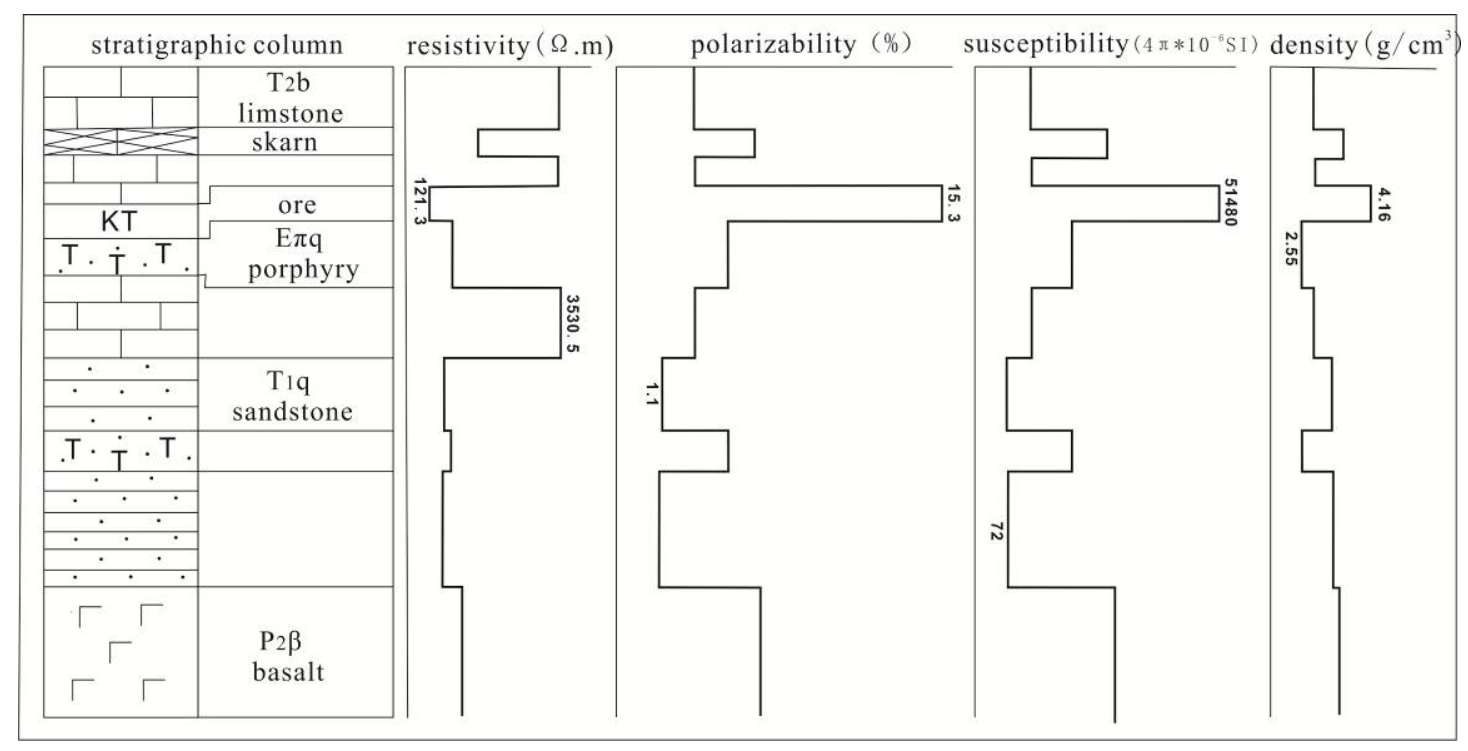

FIGURE 4. Geophysical properties of rocks 



I: $50 \Omega \cdot \mathrm{m}$; II: $2 \Omega \cdot \mathrm{m}$; III: $2000 \Omega \cdot \mathrm{m}$; IV: $200 \Omega \cdot \mathrm{m}$; V: $900 \Omega \cdot \mathrm{m}$

\section{TECTONIC SPACE RESISTIVITY MODEL}

The contact relationship and tectonics between target strata has been identified by the electromagnetic method making use of the resistivity according to the typical deposit geological model and tectonic characteristics of the mine area in Beiya Mine Area and a resistivity model has been built, as shown in Figure 5 and the physical parameters have been modified to a certain degree based on the above physical parameters, in order to highlight the anomalies of the target geological bodies. According to the known geological models of Beiya Mine Area geological model (Figure 5a), the main geological tectonics are syncline, including the first layer of rock of carbonate rocks III, the second layer of sandstone IV and subbase basalt V. Two smaller target geological bodies exist in the first layer, while porphyry body I is located in the west and iron body II located in the east. From the forward modeling map, MT can identify five target geological bodies, I, II, III, IV and $\mathrm{V}$. Theoretically we believe that it is feasible to find the tectonic and deep stratum distributions in Beiya Mine Area by using the resistivity parameters.

FIGURE 5. MT resistivity forward model

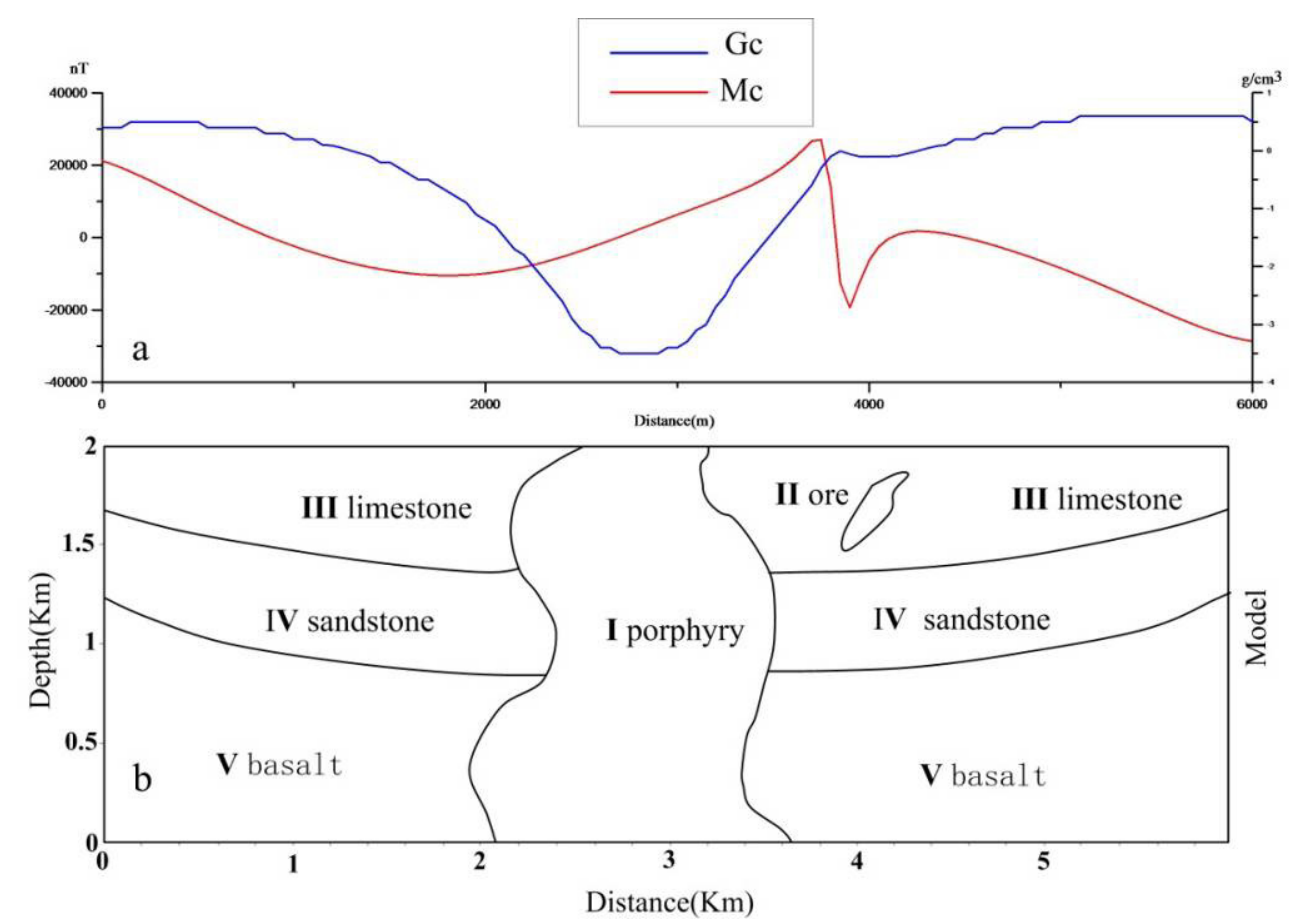

I: $2.54 \mathrm{~g} / \mathrm{cm}^{3}, 600^{*} 4 \pi^{*} 10^{-6} \mathrm{SI}$; II: $4.14 \mathrm{~g} / \mathrm{cm}^{3}, 30000^{*} 4 \pi^{*} 10^{-6} \mathrm{SI}$; III: $2.66 \mathrm{~g} / \mathrm{cm}^{3}, 400^{*} 4 \pi^{*} 10^{-6} \mathrm{SI}$ IV: $2.8 \mathrm{~g} / \mathrm{cm}^{3}, 700^{*} 4 \pi^{*} 10^{-6} \mathrm{SI}$; V: $2.81 \mathrm{~g} /$ $\mathrm{cm}^{3}, 5000 * 4 \pi^{*} 10^{-6} \mathrm{SI}$

FIGURE 6. Gravity and magnetic forward model

\section{PHYSICAL MODEL OF ORE BODY AND ROCK MASS}

The electromagnetic method is aimed to delineate the tectonic framework at the middle and deep parts and favorable metallogenic position. A gravity survey, through low-density characteristics of the rock mass, aims to look for the local low gravity anomaly. Both of the methods are focused on pointing out the prospecting direction, which is an indirect prospecting geophysical method. However, the low resistivity, high polarization and high magnetic properties of the ore body allow to carry out the magnetic method and IP prospecting pertinent to ore bodies. 
According to the above exploration ideas, in order to facilitate the forward modeling, a forward modeling has been constructed according to the skarn ore geological model and rock physical characteristics in Beiya Mine Area (Figure 6). From the perspective of the forward modeling results, regardless of the impacts of terrain, obvious low gravity anomalies occur at the rock mass and the ore body influences the local gravity anomaly. In the case of the magnetic method, the high-value anomaly of positive and negative associated with the orebody is very obvious in the absence of the reduction to the pole. From the intermediate gradient simulation of polarizability
(Figure 7), the intermediate gradient device polarizability curve and resistivity curve is reverse, i.e. low resistance high polarization and the abnormal peak of polarizability at the ore-bearing sections is high.

From the above analysis, according to the actual geological conditions in Beiya Mine Area, the gravity anomaly, regardless of the topographic effects, can reveal the projection position of porphyry on the surface, and the induced polarization method and magnetic exploration for polarizability and magnetic susceptibility parameters can be directly carried out for ore prospecting prediction.



I: $50 \Omega \cdot \mathrm{m}, 0 \%$; II: $2 \Omega \cdot \mathrm{m}, 3.5 \%$; III: $2000 \Omega \cdot \mathrm{m}, 0 \%$; IV: $200 \Omega \cdot \mathrm{m}, 0 \%$; V: $900 \Omega \cdot \mathrm{m}, 0 \%$;

FIGURE 7. Induced polarization ( IP) forward model

\section{NON-SEISMIC GEOPHYSICAL TEST IN BEIYA MINE AREA}

Based on the above forward modeling results under the theoretical model, we believe that it is feasible to find out the tectonic and deep stratum distribution by magnetotelluric sounding in Beiya Mine Area based on the resistivity parameters and it is fine to adopt the gravity exploration for rock masses by using the density parameters. The IP method and magnetic method based on polarization and magnetic susceptibility parameters have close relevancy with the ore-bearing sections.

In order to verify the actual effect of the selected method, the known ore sections o Wandongshan and Hongnitang in Beiya Mine Area have received the non-seismic geophysical technology. Magnetotelluric sounding, gravity, magnetic method and high power DC IP method have been adopted to discuss the efficiency of the method based on the constraints of various parameters.

\section{GEOPHYSICAL CHARACTERISTICS OF THE TEST AREA}

The test area is generally controlled by the NNE syncline and the syncline kernel is mostly covered by Holocene and Pleistocene sediments, while wings were affected by faults and magma intrusion and small folds have been developed (Figure 2). The main strata in the test area mainly include Quaternary Holocene alluvial containing gravel and clay and Pleistocene sedimentary facies tuffaceous breccia, lacustrine facies containing gravel clay and gravel rock; Beiya Formation carbonate; Qingshanbao Formation lithic quartz sandstone and Mount Emei basalt. The physical property statistics of all strata are shown in Figure 4.

\section{WORKING METHOD}

The 1:10,000 gravity and magnetic scanning results have been collected for the Mine Area and the mineralization favorable zone has been selected. The 1:10,000 IP scanning has been conducted for the favorable area to 




FIGURE 8. Geological map and a test section of Beiya mine

further reduce the mineralized section. Because the target layer depth in the test area is $1000 \mathrm{~m}$ minus, in order to define the contact relation of the target geological body, the AMT measurement has been carried out, with the point-to-point distance of $50 \mathrm{~m}$; the IP sounding has been conducted for the major mineralized sections to identify the characteristics of longitudinal ore body distribution with the point-to-point distance of $50 \mathrm{~m}$.

\section{DATA PROCESSING}

The secondary development of the plane gravity data has been done by the most advanced and complex gravity 3D density difference nonlinear inversion algorithm (Camacho et al. 2002), which divides the ground into a ground is divided into a number of unit bodies with fixed physical dimensions. The density difference in the unit body is a fixed value and the 3D density model has been obtained for the entire mine area through 3D the density inversion and the surface gravity anomaly has been available (Figure 5). We used the non-stationary signal analysis method, or Empirical Mode Decomposition (EMD) for the extraction of planar magnetic anomalies, which makes full use of the extreme value characteristics of the signal for the space-time filtering, fully retains the nonlinear and non-stationary characteristics of the signal itself, is well adaptive, has no restrictions on the signal (Huang 2006; Zeng \& Liu 2010) and extracts the local polar magnetic anomalies (Figure 6). The magnetotelluric sounding data processing and inversion interpretation uses the MTSOFT-2D magnetotelluric interpretation system, which comprises the data smoothing, static correction, data inversion and other modules, of which inversion models include Bostick, OCCOM, NLCG, RRI and other inversion methods and all of them can realize the pre-processing and inversion interpretation of magnetotelluric data. The profile inversion results are shown in Figure (8).

\section{INTERPRETATION OF RESULTS: PLANAR BLOCK OPTIMIZATION}

In the prospective survey of mineral resources, the regional gravity and geomagnetic data are prerequisite for the optimization of prospecting targets (Xiao et al. 1999), the surface gravity extracted through the threedimensional density inversion is abnormal (Figure 9). The Bouguer gravity anomaly in the study area is located at the negative anomaly area, with the amplitude distributed at -251.8-240.2 mGal. The Bouguer gravity anomaly in the northwest of the study area is low, and the Bouguer gravity anomaly in the southeast is high, distributed in an arch shape. The area from the north to south, to the east of Wandongshan, Weiganpo, Hongnitang, Bijiashan abd Jingouba, this section is located on the Bouguer gravity abnormal arch gradient zone. Combined with the surface geology of the mine area, it is concluded that the surface geology of the mine area, it is inferred that the eastern basalt height and gravity anomaly area exists in the mine area and Wandongshan and Hongnitang are low gravity anomaly area.

There are various sulfide minerals in the skarn deposits, including pyrite, chalcopyrite, sphalerite and galena, which can form a strong polarizability anomaly. The induced polarization method is an important method to find concealed deposits (Brian et al. 1998; Grechka et al. 1999; Rossi \& Vesnaver 1997; Yang et al. 1999) and 
the magnetic susceptibility and polarizability information can directly and effectively determine the existence of ore (mineralization). Figure 7 shows the local magnetic anomaly map extracted from the reduction to the pole in the study area, and the amplitude of the magnetic anomaly is mainly distributed at -2000-3000 nT, mainly dominated by the positive magnetic anomaly. The high magnetic anomaly can be divided into two belts, the east one and west one. The eastern magnetic anomaly zone refers to the east of Weiganpo and Bijiashan, where the anomaly continues. The western high magnetic anomaly zone refers to Wandongshan, Dashadi and Jingouba, and the surface geological data showed that the outcropping rocks in the east of Weiganpo to Bijiashan are dominated by basalt, corresponding to the high magnetic and high gravity anomaly zone could be caused by the Paleozoic basalt. Therefore, for the skarn deposit, the high magnetic and high gravity anomaly zone of the eastern part of the study area is not the key to the study. The surface of Wandongshan and Hongnitang Section has the outcropping porphyry and Triassic carbonate rocks, which can meet the mineralizing geological conditions of the skarn ore deposits, which showed the low gravity and high magnetic anomaly characteristics. Meanwhile, the IP polarization anomalies (Figure 10) at two sections have obvious low resistivity and high polarization characteristics, which can be deemed as the advantageous skarn deposit enrichment site. Therefore, two favorable blocks are divided, as shown in the black dashed box. Among them, Wandongshan is a block of proven iron ore bodies, which is being exploited and utilized. The gravity and magnetic anomaly characteristics of Hongnitang are similar to those of Wandongshan, and if there is ore (mineralization) body at Hongnitang Section is the key to the research, and further study work shall be carried out.
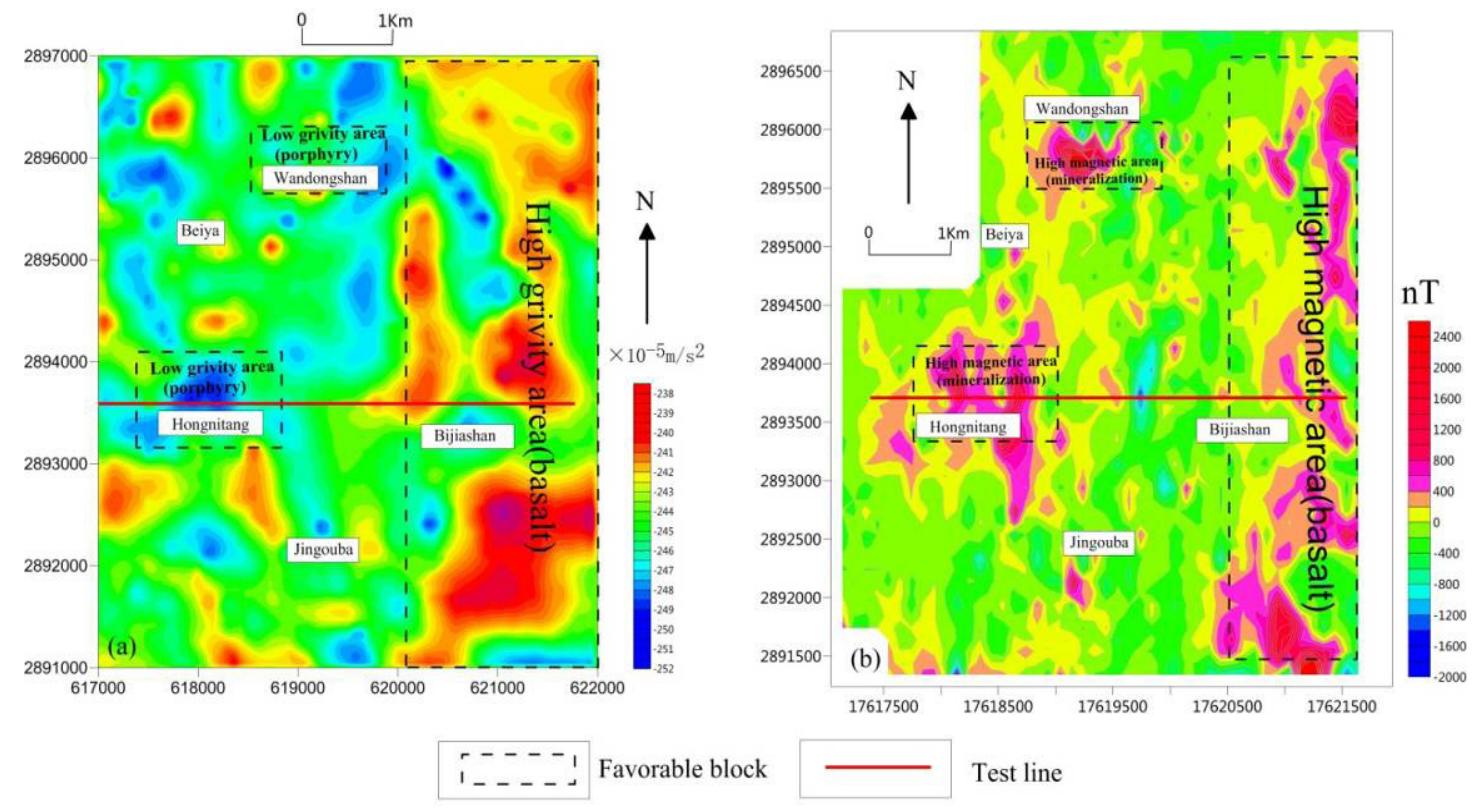

FIGURE 9. Gravity and magnetic maps of Beiya mine
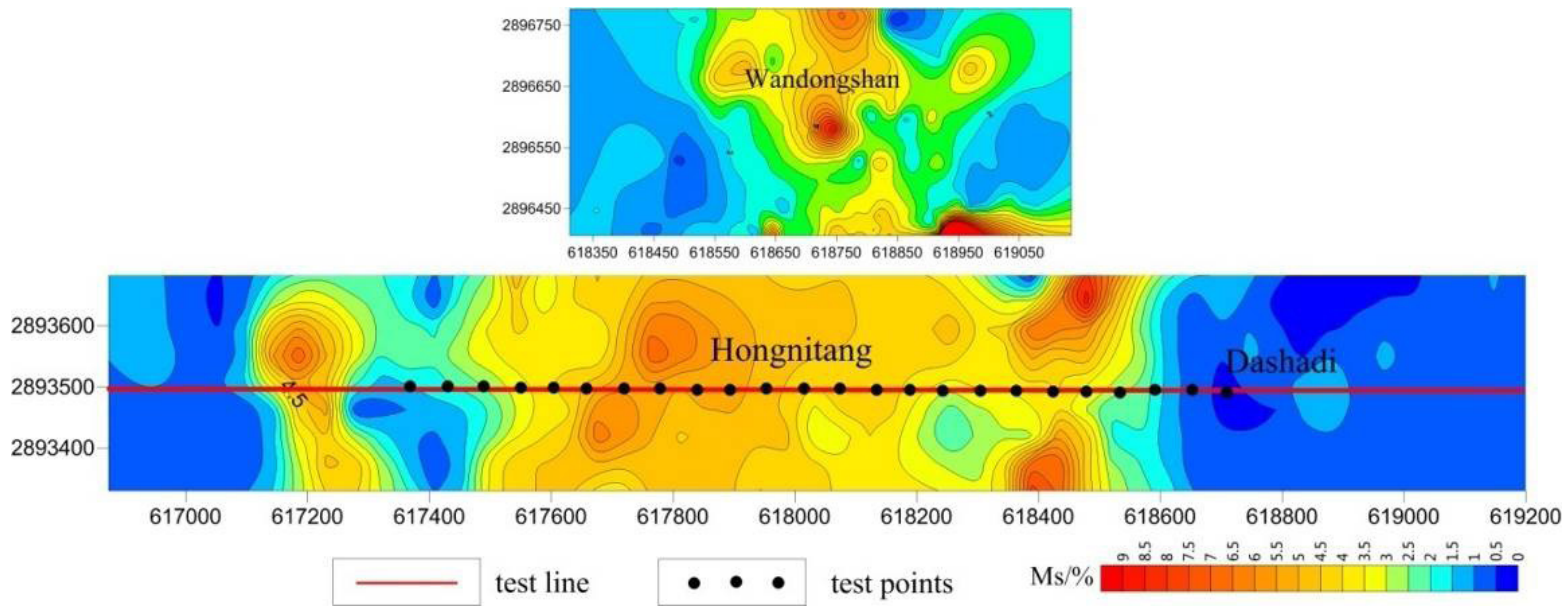

FIGURE 10. Induced polarization (IP) anomalies map of Beiya mine 



FIGURE 11. The line 55 gravity and magnetic inversion profile of Hongnitang ore section

\section{INTERPRETATION OF RESULTS - PROFILE CONTROL AT THE KEY SECTIONS}

A comprehensive profile is deployed passing Hongnitang IP anomaly center, which passes through Hongnitang, Dashadi and Bijiashan. Among that, AMT point-to-point distance is $50 \mathrm{~m}$, the gravity magnetic profile point-topoint distance is $25 \mathrm{~m}$ and the IP sounding point-to-point distance is $50 \mathrm{~m}$ (see Figure 8 for details).

The density and magnetic susceptibility parameters of all strata and rock masses are initial values of density and magnetization parameters from physical property testing and statistics. By the establishment of different models, the forward modeling tentative calculation shall be done to highlight the magnetic anomalies caused by the gravity anomaly of the rock masses. Through the correction of the initial parameters and comparison of forward modeling results, the stratum interpretation model is regarded as the initial model, the density corrected by the forward modeling as the parameter, porphyry and orebody as the major fitting target. The two-dimensional constraint inversion has been done for the gravity and magnetic anomalies of this profile. This inversion profile (12) shows that the low density anomaly could be caused by the porphyry, and the concealed the porphyry in Dashadi is caused by the intrusion by Hongnitang along the weak aspect of rock stratum, i.e. the concealed rock mass at Dashadi is a branch of Hongnitang rock mass. Due to the influence of resolution, Hongnitang rock mass and Dashadi rock mass has shown as being connected as an entirety in terms of gravity anomaly. The profile inversion results of magnetic anomaly show that the magnetic anomaly is 'high at ends and low in the middle'. The peak $1600 \mathrm{nT}$ appears at Hongnitang - Dashadi Section, which is a high magnetic anomaly zone. The magnetic anomaly amplitude is generally at about $1000 \mathrm{nT}$ and the abnormal shape is in the 'sawtooth' shape on the contact zone of rock mass. With regard to the physical property, porphyry and sedimentary rocks feature weak magnetic properties, insufficient to have such a high local magnetic anomaly. Mount Emei basalt has strong magnetism, but it is impossible to cause the local high magnetic anomaly due to the large burial depth. With regardless of the impact of the rock masses, strata and rock and basalt, the local high magnetism from Hongnitang to Dashadi could be caused by skarn zone or magnetite ore (mineralization).

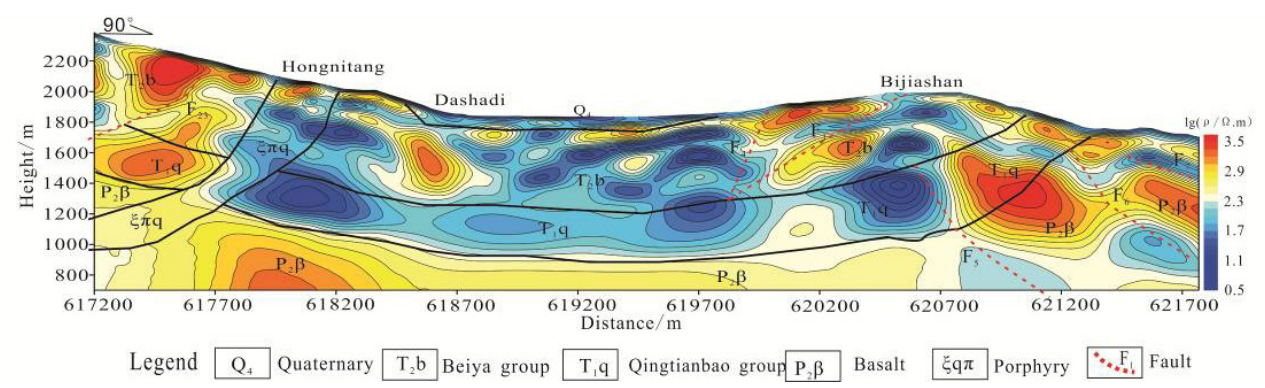

FIGURE 12. The line 55 AMT inversion profile of Hongnitang ore section 
From the inversion results of Hongnitang Line 55 AMT inversion, the electrical structure in this area is complex, which shows the overall obvious transverse blocks and vertical stratification, and the resistivity value is high at both ends and low in the middle. The resistivity in the west of Hongnitang is represented by the block high resistivity anomaly and the electrical property from Hongnitang to Bijiashan shows a belt or block discrete high/low and the resistivity in the east of Bijiashan shows the strip and block high resistivity anomaly, interspersed with the thin layer low resistance anomaly zone. Three faults, F1, F2, and F3 have been interpreted and three concealed fractures F5, F6 and 7 have been inferred according to geological data. The $\mathrm{F} 1$ fault is invisible at the surface. According to the electric anomaly, it is believed that F1 fault exists and converges with F4 at the depth, crossing through Beiya Formation and Qingshan Bao Formation strata. In the Mount Emei basalt stratum in the east of Bijiashan, the strip low resistivity anomaly is interspersed between blocks of high resistivity anomaly body. These low resistivity can be considered to be caused by faults or porphyry. This area is not suitable for generating a skarn deposit, i.e. the Beiya Formation carbonate rocks of mineral accumulation layer. This low resistivity zone is interpreted as the diagenesis branch for looking for skarn deposit and interpreted as the fault.
Seen from the polarizability profile, the polarizability anomaly is 'low at ends and high in the middle' and the apparent polarizability amplitude at Hongnitang Section is higher than that of Dashadi on a whole. The apparent polarizability amplitude at Hongnitang Section is mainly distributed at $2.1 \%-4.8 \%$, anomaly extreme value up to $5.29 \%$, which is categorized as the high polarizability anomaly. The apparent polarizability amplitude of western Dashadi Section is mainly at about $2 \%$, which is categorized into the moderate polarizability anomaly. The eastern Dashadi Section has small apparent polarizability amplitude, which is a background field. Based on the apparent polarizability information, the sounding scope is further narrowed and the IP sounding should be done from western Hongnitang to the western Dashadi. From Figure 13 of the IP sounding polarizability, the polarizability shows high at the shallow part and high at the depth. The polarizability is distributed in a strip or block shape, at the core area with the high extreme value greater than $4 \%$, with abnormal enclosure. It is distributed at the lower contact zone at Hongnitang rock masses and Beiya Formation carbonate rocks, including the internal contact zone and external contact zone. This contact zone is the favorable position forming the contact metasomatic deposits, and the high polarizability anomaly is interpreted as the ore body (mineralization).


FIGURE 13. The line 55 Induced polarization (IP) anomalies and interpretation model of Hongnitang ore section

\section{INTERPRETATIONS OF RESULTS: COMPREHENSIVE INTERPRETATION AND OREBODY LOCATION}

Figure 14(b) exploration line profile is generally a wide and gentle syncline structure and the syncline kernel is covered by Quaternary strata and the strata, from the bottom to top, including Permian basalt, lower Tongqing Tianbao Formation clastic rocks and middle Triassic Beiya Formation carbonate rocks. Multiple near SN fractures are developed on both wings on the syncline and the rock mass is located in the west wing of the syncline. The lithology is quartz syenite porphyry and the contact zone between rock masses and surrounding rock has developed skarn alteration, associated with magnetite mineralization, limonitization, chalcopyrite, and pyrite. The orebody is in the strip shape, with the stratiform occurrence. 
Combined with the interpretation model of the rock mass and interpretation model of the ore body, a comprehensive geological interpretation model is constructed, as shown in Figure 14(a). Comparison with the prospecting line profile, it is interpreted that the profile as the syncline structure. The faults outcropping on the surface, F23, F1 and F4 are interpreted, including the extension direction. The fractures F4 and F1 cross with each other underground and in other words, the F4 fracture is the secondary fracture of $\mathrm{F} 1$, which provides the geological evidence proving that ' $\mathrm{F} 4$ is a steep and inclined tension fracture of F1 hanging side'. At the same time, 3 concealed fractures have been interpreted in the east of Bijiashan. Restricted by the resolution of geophysical methods, it is concluded that the geometrical structure is not as fine as the engineering control, but it can determine rock intrusive channel, which is important for identifying the prospecting direction and studying the metallogenic model. The project controls two ore bodies, KT1 and KT2 and it interprets the corresponding thick and large deep orebody KT2. From the geological exploration line model, the ore body KT2 exists on the outer contact zone between the rock mass and Beiya Formation carbonate rocks, and the orebody is distributed at the inner and outer contact zones o the rock mass. According to the comprehensive interpretation map and exploration line map, the distribution of the stratum, tectonics, rock masses and orebody has been interpreted by using the method of multivariate information and the good prospecting effects have been achieved. It is feasible for prospecting the concealed skarn type iron deposits.

(a)

(b)

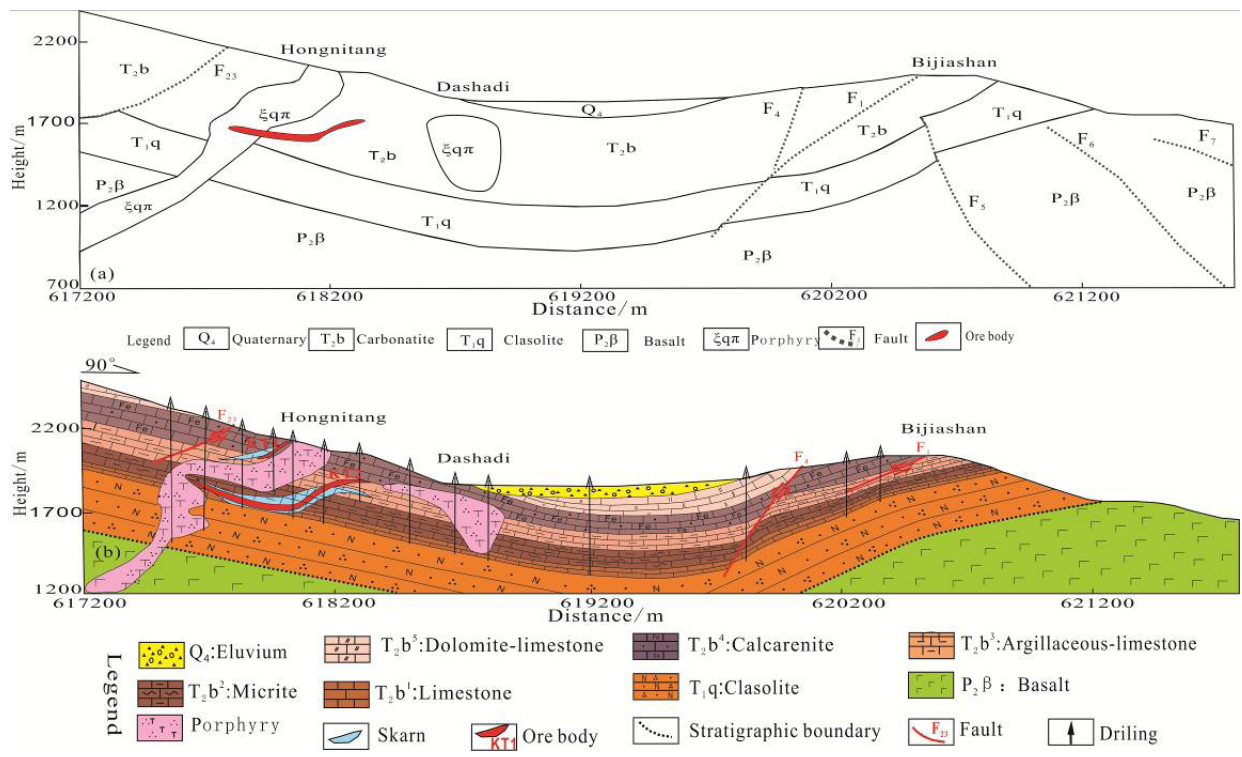

FIGURE 14. The line 55 comprehensive interpretation of geological model and actual geological model of Hongnitang ore section

\section{NON-SEISMIC GEOPHYSICAL EXPLORATION MODELS AND COMBINATION OF METHODS}

Supported by the guidance of geology theory, different geological problems have been addressed by different methods and parameters. Combined with the comprehensive geophysical exploration testing techniques, the combination of non-seismic geophysical exploration model and method has been summarized and proposed:

The basic and model physical property model is the basis of geophysical exploration. Based on the regional geology, deposit and orebody geological characteristics of Beiya deposit, combined with the analysis, knowledge, and summary of physical property statistics, the typical deposit structure space and orebody geophysical model of Beiya Mine Area has been constructed. The forward modeling results show that through the difference of resistivity, the deep stratum structure distribution can be obtained.
Through the density difference, the contact relation between the moderate acid rock mass and cofferdam is determined by defining the local gravity low anomaly caused by the density difference, and the prospecting direction is preliminarily determined. Through the magnetism and polarizability difference, the prospecting work can be done directly.

By means of area gravity and magnetic measurements, the plan gravity and magnetic anomaly distribution are obtained and the possible scope of alkali-rich porphyry and magnetite enrichment zone is roughly delineated for a section of blocks.

The characteristics of underground local strata distribution have been clarified by using the observed AMT long profile and large scale, combined with the drilling and logging data. Meanwhile, the ore-forming 
tectonics of fractures and lithologic mutation interface has been clarified. Favorable metallogenic sections have been classified based on the medium or small scale, and the accuracy of geological interpretation has been strengthened by using the gravity-magnetic-electric multiparameter constraints.

In the mineralization, favorable enrichment areas which have been delineated by the ground gravity and magnetic and AMT, the IP area measurement has been carried out to further narrow the favorable position by the polarizability anomalies directly oriented to the sulfide minerals. By means of the polarization sounding, the vertical distribution characteristics of polarized bodies have been clarified to further modify the plane abnormal position.

Taking advantage of the multivariate information constraints, the strata, structure, rock masses and ore bodies have been interpreted, a comprehensive geological interpretation model has been established, and the effectiveness and the feasibility of the geophysical exploration and its method combination has been verified by drilling.

\section{CONCLUSION}

The deposit is the product of comprehensive effect of various kinds of geological factors and different deposits have unique attributes. In view of the properties of rock ores, we have combined the metallogenic model of geophysical exploration model and established a comprehensive interpretive geological model by using the gravity-magnetic-electric and geological methods after extensive exploration. Good exploration results have been made by comparing the exploration line geological model. We have put forward a locating method adaptive to the concealed skarn iron deposit in Beiya, which makes up the shortcomings of a single method, has formed a multiscale and multi-parameter comprehensive prospecting combination. It has provided the theoretical basis for the promotion of the prospecting evaluation, peripheral prospecting and analyzing the similar geological mineralization background in the mine area.

\section{ACKNOWLEDGEMENTS}

We would like to extend our thanks to China Geological Survey for the project and funds support.

\section{REFERENCES}

Brian, S.A., Mark, E.W. \& Jogn, E.B. 1998. A Report on the Renaissance of Gravity in the Deep Water Gulf of Mexico: A Practical View of Integration Methods. In annual meeting abstracts. Society of Exploration Geophysicists. pp. 515-517.
Camacho, A.G., Montesinos, F.G. \& Vieira, R. 2002. A $3-\mathrm{D}$ gravity inversion tool based on exploration of model possibilities. Computers \& Geosciences 28(2): 191-204.

Grechka, V., Theophanis, S. \& Tsvankin, I. 1999. Joint inversion of P-and Ps-waves in orthorhombic media: Theory and a physical-modeling study. Geophysics 66(1): 146-161.

He, Z.H., Zhou, Y.M. \& He, W.Y. 2013. Genetic types and metallogenic regularity of Beiya superlarge goldpolymetallic deposit, northwestern Yunnan. Mineral Deposits 32(2): 244-258.

Huang, N.E. 2006. An adaptive data analysis method for nonlinear and nonstationary time series: The empirical mode decomposition and Hilbert spectral analysis. Applied and Numerical Harmonic Analysis. Switzerland: Brikhauser Verlag Basel. pp. 63-37.

Li, J., Ding, J. \& Niu, H.B. 2016. Geochemical characteristics of magnetite from Beiya gold polymetallic deposit in western Yunnan and its constraint on mineralization. Mineral Deposits 35(2): 395-413.

Liu, G.D. \& Hao, T.Y. 1995. Searching of hidden mineral deposits by geophysical methods. Chinese Journal of Geophysics 6: 618-626.

Liu, J.X., Sun, H.L. \& Chen, B. 2016. Review of the gravity and magnetic methods in the exploration of metal deposits. Progress in Geophysics 31(2): 713722.

Rossi, G. \& Vesnaver, A. 1997. 3-D imaging by adaptive joint inversion of reflected and refracted arrivals. In Annual Meeting Abstracts. Society of Exploration Geophysicists. pp. 1873-1876.

Sirajuddin, N.A. \& Md. Jamil M.S. 2015. Self-healing of poly (2-hydroxyethyl methacrylate) hydrogel through molecular diffusion. Sains Malaysiana 44(6): 811-818.

Sultana, M.N., Akib, S. \& Ashraf, M.A. 2017. Thermal comfort and runoff water quality performance on green roofs in tropical conditions. Geology, Ecology, and Landscapes 1(1): 47-55.

Wu, H., Zhao, B. \& Gao, W. 2017. Analysis of gradient descent ontology iterative algorithm for geological setting. Geology, Ecology, and Landscapes 1(1): 4146.

Xiao, K.Y., Zhu, Y.S. \& Zhang, X.H. 1999. The extraction and integration technology of minerogenic information in mineral resource assessment. Mineral Doposits 18(4): 379-384.

Yang, C.H., Tong, L.T. \& Huang, C.F. 1999. Combined application of DC and TEM to sea-water intrusion mapping. Geophysics 64(2): 417-425.

Yin, F.G., Sun, Z.M., \& Ren, G. 2012. Geological record of paleo-and mesoproterozoic orogenesis in the western margin of upper Yangtze block. Acta Geologica Sinica 86: 1918-1932. 
Zeng, Q.Q. \& Liu, T.Y. 2010. A potential field separation method based on empirical mode decomposition. Oil Geophysical Prospecting 45: 914-918.

Jian Yang*, Qiao Wang, Shengxian Liang \& Jing Guo Chengdu Center, China Geological Survey

Chengdu 610081

China
Muhammad Aqeel Ashraf

International Water, Air \& Soil Conservation Society 59200 Kuala Lumpur, Federal Territory

Malaysia

*Corresponding author; email: 115138871@qq.com

Received: 25 January 2017

Accepted: 25 May 2017 